\title{
James Cowan: Autobiographical Historian and Traveller in Time
}

\author{
MICHAEL BELGRAVE
}

\begin{abstract}
James Cowan's childhood, growing up on the family farm built on the site of the Battle of Örākau, has always been seen as an influence in his writing, particularly as a historian. This article explores Cowan's world on the frontier, as a child in the 1870s, but more importantly as an adolescent in the early 1880s. Not only was Cowan's experience of these tense and sometimes turbulent decades a major influence on his writing, they also help us explain some of the contradictions presently seen in work. On the one hand, Cowan echoed nineteenthcentury notions of colonial virtue and argued that the wars drew Māori and Pākehā closer together. At the same time, he was prepared to call confiscation of Waikato land theft on a massive scale. Cowan's ability to be a historian of the time, while also reflecting a critical perspective of colonisation, reflected the world of the frontier in the early 1880s. Attempts to make peace between the King and the Queen created an atmosphere of reconciliation, where the protagonists of the 1860s, including Rewi Maniapoto, Wahanui Huatare and Te Kooti Arikirangi te Turuki negotiated for a new peace with old enemies, George Grey, John Bryce and William Gilbert Mair. Cowan's writing reflected familiarity with these peace makers, but also made him conscious of the failure of the negotiations to resolve grievances over confiscations. Cowan's was a personal history, forged not in archives, but through personal relationships built on interviews and correspondence.
\end{abstract}

Peter Gibbons and Chris Hilliard have both discussed James Cowan as a member of a cohort, a group of writers coming of age after the 1890s and active before the Second World War, contributing to what Gibbons has called a "literature of occupation." Between the 1890s and the 1930s, European writing about New Zealand was dominated by amateurs, and focused on New Zealand's role as colony and dominion within the Empire. Writers were absorbed by a literature of settlement, normalising New Zealand's European past and making the foreign in the New Zealand environment familiar. To some extent Cowan fitted the role. He set out to give New Zealand a history, one that was popular and local, a Boy's Own past of heroism and adventure, but one that firmly located Europeans as the conquerors of a different and at times hostile environment. Yet Cowan is distinctive because he both represents the period and transcends it. His writing echoed earlier eras but also anticipated much that followed him. Cowan's interest in the colonial frontier and his use of informants such as Gilbert Mair and Thomas Porter gave voices to Gibbons' earlier, pre-1890 period, to the "factotems of invasion." And, however dated Cowan had become by the 1960s, he shared an ambivalence, even contempt, for Empire with his professionalised post-World War Two successors. As a historian and journalist making his living outside the university he had much in common with Michael King, two generations later. At the same time, Cowan's willingness to remind Waikato settlers that they occupied stolen land provided a prequel to recent Waitangi Tribunal history, while his ethical use of oral history appears far more professional by today's standards than it did in the 1960s. This article tries to resolve these tensions, to provide an explanation for these different facets of Cowan's writing.

The influence of Cowan's childhood at Ōrākau on his writing has long been recognised. ${ }^{2}$ This chapter explores Cowan's growing up and in particular his adolescence. It argues that many of the contradictions seen in Cowan's approach to war, colonisation and relationships between Māori and settler have their origins in this crucial dramatic period in his life and in the nature of the relationships he experienced with the Māori and European

Journal of New Zealand Studies NS19 (2015), 50-62 
inhabitants of the borderland of the Rohe Pōtae. These were men with dramatic histories, heroes and villains of the war, trying to find accommodations with each other in a period that was still marked by tensions and threats of further hostilities. This experience as a childhood observer helped mould Cowan's understanding of time and this understanding is crucial to Cowan's treatment of the past, his use of oral history and his belief both that the wars brought Māori and Pākehā together and that the confiscations were a gross and unresolved injustice.

Cowan grew up in interesting times and in the best place to experience them. His family moved onto the site of the 1864 battle in 1870, not long after he was born, and it was here that he lived until he moved to Auckland as an 18-year-old in 1888, to work as a junior reporter on the Auckland Star. ${ }^{3}$ While elsewhere the war was over, in the Waipa it continued. The settlers were armed, and alongside kūpapa soldiers they were defending a cold war frontier which divided the Queen's forces and the Queen's law from those of the King. This frontier was the aukati, the barrier to the Rohe Pōtae, the King Country. The young Cowan fossicked around the Ōrākau trenches, developing a life-long fascination not only with battle sites and the events which created them, but with how they could be forgotten and why they should be remembered. All the while he searched for buttons or bullets, or the $£ 500$ treasure rumoured to be buried there, he and his family were under constant threat that some unexpected trigger would reignite a war. ${ }^{4}$ As he grew older, the tensions eased and the bogymen of settler childhood, such as Rewi Maniapoto and Wahanui Huatare, transformed themselves into calming mediators between the Kingitanga and the settlers. Once-feared rebels became familiar visitors in the small border towns of Kihikihi and Alexandra (Pirongia) and even King Tâwhiao made royal visits to Raglan in 1878 and the other Waikato towns in 1881. Cowan was certainly present when Tāwhiao and 76 supporters symbolically handed over their weapons to William Mair at Alexandra in July 1881, marking peace between the races, but not submission to the colonial government. ${ }^{5}$ High-level negotiations brought Sir Donald McLean, Sir George Grey and John Bryce to parley with the Kinngitanga in long dramatic hui attended by thousands.

By the time Cowan joined the Star the aukati was gone. In 1885, Wahanui of Ngāti Maniapoto and the Premier, Robert Stout, turned the first sod for the main trunk line inside the Rohe Pōtae. This symbolic event marked the opening up of the Rohe Pōtae and the closing of the New Zealand frontier. ${ }^{6}$ The closing of the frontier in the United States in 1890 accelerated the commodification of nostalgia, for what Europeans romanticised as the once free Indian. Geronimo had his Cadillac and William F. Cody (Buffalo Bill) his Wild West Show. The historical West was refashioned by Frederick Jackson Turner as the source of American democracy. ${ }^{7}$ New Zealand's experience was a close parallel, both chronologically and culturally. Essential to both lost frontiers was the idea that the past could only be evoked through imagination or memory, because it could no longer be experienced in real time. Cowan's early life and his writing would traverse this frontier, launching from his own memory into a time forever gone, where his own experience of growing up connected him to events that were rapidly moving from memory into history. In his writing, history and memory combined, augmented by the recollections of his informants, both Māori and Pākehā. These informants extended Cowan's first-hand history back as far as the wars of the 1840s. Through this approach, Cowan's writing became a travelogue in time as well as place. History became a form of time travel, of being transported to a time and place before the end of the frontier and the arrival of modern New Zealand.

Cowan's formative experience on the sacred ground of the Ōrākau battlefield, mingling with Māori on both sides of the Rohe Pōtae, did not determine what kind of writer he became, did not fashion his sympathies or spark his prejudices. He could quite easily have treated the Māori world around him with contempt, and have chosen civilisation as the inevitable path of history, to be irrefutably applauded. His neighbour on these borderlands, 
Andrew Kay, although older and admired by Cowan, had little sympathy for the Kingitanga and even in 1914 still claimed Grey's attack on the Waikato had thwarted a violent invasion of Auckland. Cowan's experience on the frontier, the shaping of his memory, took a different form: his relationships on the frontier brokered his understanding of the role of the historian.

Cowan grew up as the idea of Māori independence blossomed and then died away, accompanied by intense pressure from the colonial government to "open up the King Country." During all of this period the aukati defined the difference between an independent Māori space and encroaching Europeanisation. The aukati divided two worlds becoming increasingly distinct during Cowan's childhood and then rapidly coalescing as he began his career as a journalist. As one of his colleagues writing for the Railways Magazine put it:

The Puniu River, un-bridged and unfordable in flood season, was the boundary. On one side, where the white man reigned, there were tidy farms, cosy houses, schools, shops, and churches with sounding bells. But, to the mystic South, there lay long faintly blue distant ranges; here and there a raupo thatched village; random patches of potatoes, maize or wheat; long stretches of fern and swamp, and again and again, the endless dim green aisles of the bush, its mossy floor lying in perpetual twilight. Its awesome silence was only broken by the melodies of bush birds, the weird noises of wild pigs and the sudden scurry of wild Maori horses. Maori tracks for man and horse were the only roads, and dignified Maori chiefs ruled with kingly power. ${ }^{8}$

Civilisation as Cowan understood it lay on one side and a primeval world on the other. The aukati defined the identities of those living on both sides of this frontier, particularly as the frontier did not preclude ongoing economic, diplomatic and social intercourse. But at the same time the frontier was the result of an unresolved and undeclared truce:

Looking southward across the Puniu in the Seventies and early Eighties we who were bred up on the Frontier saw a mysterious-appearing land, fascinating to the imagination because unknown - a land, too, of dread in the years of unrest, for there in the hinterland only a few miles from the border river lived Te Kooti and his band and the hundreds of Waikato dispossessed of their good lands on which we pakeha families now dwelt. ${ }^{9}$

The twenty years of Kingitanga independence after Ōrākau and the need for both sides to make peace overlaid the reality of frontier life. ${ }^{10}$ During Cowan's early years, relationships between the British Crown and the Māori King were nervous and distant. Kihikihi was called the "Listening Post," because spies were run from the border town into the Rohe Pōtae, from which the colonial government was excluded. ${ }^{11}$ But by the late 1870 s, negotiations commenced in earnest, bringing Sir George Grey, John Sheehan and later John Bryce and then John Ballance into the Rohe Pōtae, accompanied by thousands of participants, all seeking to make peace, and to produce some form of constitutional accord which defined the parameters of the future. ${ }^{12}$ Māori from around the country attended these hui, hopeful of a broader constitutional arrangement that would flow into their own areas.

Much of the way that Cowan approached the past was influenced by a mixture of nostalgia for the lost frontier and ambivalence toward the twin gods of modernity and progress. Central to Cowan's borderland is the way that time was experienced, defining the idea of the past, the metaphors through which change was understood and the way that some things appeared to change faster than others. Perceptions of time on the borderland had several contradictory qualities, which underpinned the relationships Cowan had with family and European neighbours and with Māori on both sides of the aukati. There are two points on 
the borderlands when time begins. The first of these is the most immediate. It is the time when the aukati was created, when the sacking of Rangiaowhia and the battles of Hairini and Ōrākau closed the door to a Garden of Eden created by Māori labour and entrepreneurship fed by the seeds of European ideas and horticulture. In Kāwhia the war also destroyed a vital new garden economy, as Cowan noted, quoting Ngarongo:

No more wheat or maize was grown, no flax-scraping was done, and the trading vessels lay deserted at anchor, for there was no one to man them. The soil was not cultivated, the flourmill wheels ceased to turn. The winds wailed over a deserted Kawhia, when the men, young and old, had girded themselves with the belt of war and gripped their guns and other weapons of war and marched away... ${ }^{13}$

These gardens were not primeval, but an Eden created by missionary endeavour and inspiration and Māori labour and openness to civilisation and Christianity. Around Te Awamutu, Rangiaowhia and Ōrākau were Christian towns in this Eden. Rangiaowhia was:

a beautiful place, with its comfortable thatched houses, shaded by groves of peach and apple trees, dotted along the crown of a gently sloping hill among the fields of wheat, maize, potatoes and kumaras, and its flourmills in the valley. ${ }^{14}$

While confiscation transferred the peach groves to European ownership, post-war peaches were never as large or their flesh as luscious as those ante-bellum peaches in memory and imagination. Almond trees grew thirty feet high in front of the Morgans' mission house. In such a garden, the battles took place. Cowan began his chapter on Örākau, with: "Orakau ("the Place of Trees") lay among its fruit-groves and its cultivated fields, gently tilted to the quarter of greatest sunshine." 15 Ploughs were not turned into swords at Ōrākau, but Cowan would recount peach stick being turned into shot, when the lead ran out. Talking of his own childhood farm, his earliest memories were of "fine old groves of peaches and cherries, its great almond trees and its relics of vanished Maoridom."16 After the war, settlers cut the trees for firewood.

Earlier time is Māori time, a time recorded in myth, but still imprinted by memory on the landscape. Cowan the oral historian made little distinction between myth and history; the sources for him were the same and had the same integrity. The war that split Eden asunder divided the Māori and the European world, left civilisation on the European side of the aukati on confiscated land, and re-established the earlier pre-Christian world on the Māori side. For Europeans there was progress, but progress was still a fallen Eden, tarnished by the stain of a confiscatory war. On the Māori side of the aukati, cultivation of European crops continued, but Eden was no more, and a primeval Māori world re-emerged in the "wastes of fern and manuka southward of the Puniu River."17

As the contrast between these two worlds became more accentuated through Cowan's childhood and early teens, particularly with the growth of the towns of Cambridge, Te Awamutu and Hamilton and the arrival of the railway, the Māori world of the aukati appeared to Europeans caught in a moment of the past and unchanging, while everywhere modernity and civilisation were rapidly advancing. European progress accentuated the primordial in the landscape across the aukati. Once the King Country was opened up, time would also catch up and the Māori world of the past would be swept away. Although Cowan often described the aukati as a firm barrier, it was more a flax curtain, and his stories described people going from one side the other, often at risk. Crossing the border was often described as a journey through time. Cowan and his other European commentators often mistook the absence of infrastructure as a sign of economic inactivity, but Māori agriculture was more successful across the aukati than it was on the small, easily exhausted plots on the European side. ${ }^{18}$ 
Cowan's historical writing strung together a series of dramatic incidents, with a focus on the heroic and the dangerous. For a journalist making his living writing history, this is hardly unsurprising. However, the rhythm of his writing also reflected the tempo of frontier life during his childhood and adolescence. Living on the aukati was accompanied by an everpresent threat of violence. Cowan was well aware of this threat:

What wonder if many of the warriors, old and young, whose settlements stood a few miles to the south of the Puniu River had one great ruling passion, the hope to ride with gun and tomahawk from one farm and one township to the other across the border, exacting "utu" from the pakeha! ${ }^{19}$

The settlers were an army of occupation, expecting to drill and to be called to defend the frontier from Kingitanga incursion. All along the line were blockhouses and redoubts. Cowan tended to overstate the military preparedness and the efficiency of these part-time soldiers, reflecting more the reassurances given a young child at the time, than their actual state of readiness. ${ }^{20}$ For most of the time, the risk was low, and the part-time soldiers and their families went on with their usual lives, working their small farms, attending the sports days, race meetings and the agricultural shows, which punctuated and alleviated rural isolation. Being on a borderland was being on the edge of the European world, distant from the comforts of Auckland.

All this changed for Europeans on the aukati when isolated events, often associated with a homicide, turned complacency into alarm. The humdrum, day-to-day world of frontier life immediately gave way to one of excitement as anxiety, rumours and speculation spread almost instantly up and down the line, encouraging fears that these deaths could trigger a more general outbreak of hostilities. The soldiers were called out and began drilling more vigorously; telegrams were dispatched to government officials; and all eyes were cast across the aukati for signs of marauding parties. These events turned the frontier from a forgotten part of the colony to a place of utmost importance; a place where the outcome of these dramatic events could have an impact on the future of European communities in the North Island. When the large-scale negotiations took place between 1878 and 1885, they brought leading figures of the colonial government and the newspaper attention of the country into the borderlands. Through these negotiations or through public panics the borderlands moved from the edge to the centre of national consciousness.

The discovery of a body, unexplained discharges of weapons, fires and thefts and the meanderings of groups of unknown Māori-everyone was armed-fed these European panics. They could only be eased when uncertainty gave way to reassurance, when as in many cases murder was shown to be personal rather than political, and often when someone like Rewi Maniapoto dismissed them as of no consequence. In all the uncertainty, Rewi's voice had become calming and authoritative for soothing the skittish anxieties of those Europeans bordering the aukati. These were times which "produced tensions that sometimes all but reached breaking point." 21 In 1870, the year of Cowan's birth, a surveyor, Richard Todd, was killed, and in 1873, a farm worker, Timothy Sullivan, was killed in similar political circumstances. James Mackay was sent to investigate and was attacked inside the aukati. ${ }^{22}$ As a result of Sullivan's death, the government stepped back from its programme of Native Land Court investigations across much of the central North Island. One such event, and one whose impact Cowan would have been old enough to have experienced first-hand, was the attack upon and imprisonment of Charles Wilson Hursthouse and his surveying party in 1883. Significantly, it was Te Kooti Arikirangi Te Turuki who "came to the rescue.",23

As a child, Cowan knew that the men who wandered through Kihikihi or Te Awamutu were famous. His childhood memories of these men informed his later professional depiction of them. These memories were first-hand, but distant, informed by the pointing and 
whispering of elders, but also windows of imagination into the excitement of their pasts. Cowan's interpretation of Te Kooti was led by this personal experience of the man, in the years following 1882 when he was pardoned and free to travel anywhere-except the East Coast. Cowan's Te Kooti was a "quiet if sometimes convivial neighbour," living next to the Cowans on a poor piece of land granted him by the government, and who raced his horse, Panirau, in the Kihikihi Cup. ${ }^{24}$ Cowan did not draw a particularly complex Te Kooti, but he did make him a man of contradictions: brutal and treacherous in his campaign on the East Coast, but a superb general and leader of men and, more importantly, in later life a man of peace. Te Kooti's military campaign against the government was for Cowan largely explained, even justified, by his wrongful imprisonment on the Chatham Islands. He was not an ignoble savage, in Cowan's narrative, giving way to the base passion of the primitive, but a universal villain, as much a figure of European as Māori history:

Te Kooti undoubtedly had the criminal instinct writ large all over him. He would have made a highly successful pirate had he lived on the Spanish Main. Had he continued to follow the sea-he was a sailor when a young man-he might have had a picturesque sensational career as a smuggler and ship stealer, and generally have out bullied that famous Captain Hayes. However, fate made the Maori War captain"General" the Maoris called him-and he wrote in a finger of blood on the pages of our brief colonial history. ${ }^{25}$

His force was elsewhere described as "murderous caterans," 26 like marauding Scottish clans, and his violence that of a pirate. By the time of his exile in the Rohe Pōtae, he was a man out of place, isolated from his past, his home and most of those who had supported him. Still significant as a leader and prophet and a builder of wharenui, he had become a man of peace. ${ }^{27}$ In 1888, accompanied by Gilbert Mair, Cowan met Te Kooti and interviewed him. Like Rewi and Wahanui Huatare, Te Kooti was a familiar figure in Cowan's upbringing, physically close at times, but only knowable through conversation or interview after Cowan had moved away to Auckland and returned with the status of journalist. These men's violent pasts and even their threat to the present peace gave them an air of excitement. But their role as peacemakers and negotiators, familiar strangers, was the lens through which Cowan approached the earlier events of the 1860s.

Cowan's understanding of the parts played by Rewi and Wahanui on the aukati reflected the roles they played at different times in his childhood and adolescence. He always depicted Rewi as the military hero of Ōrākau, the valiant defender of Māori nationalism against the military might of empire. Cowan greatly expanded and further popularised the mythology of Rewi as military leader in his history of the New Zealand Wars, and through his contribution to Rudall Hayward's two films whose common title, Rewi's Last Stand, celebrated the Ngāti Maniapoto rangatira's role at Ōrākau. ${ }^{28}$ But in the 1870s, Rewi transformed himself from military hero into celebrity negotiator and mediator, a transition which reflected his considerable skills as diplomat and his shrewd ability to exploit his fame. He was spokesman on behalf of Ngāti Maniapoto and Raukawa, a role he undertook with considerable skill, mediating between those demanding that the Kingitanga take a more aggressive role in resisting European encroachment and the colonial government and local settlers. Too young to appreciate its significance, Cowan made little or no mention of this aspect of Rewi's career.

By 1882, the negotiating leadership of Ngāti Maniapoto had passed from Rewi to Wahanui Huatare. Cowan had a much more mature understanding of Wahanui's stature and abilities as a negotiator. Even then, Cowan's descriptions of Wahanui come from the mid1880s when he was appearing before the Native Land Court and in turn was handing over responsibilities for tribal leadership to a new generation in John Ormsby. As Wahanui did not 
appear before the Court in the early 1880s, Cowan misplaced his earliest memories of the man:

In the days of the young Eighties, when we saw the great mouthpiece of the Kingites striding with that proud, disdainful bearing that was always his characteristic, along the road to the Land Court, he was indeed a man of weight in the world. ${ }^{29}$

He was a man of huge size, eloquent speech and great bearing, a physical presence imprinted on the young Cowan's memory. Whereas Rewi remained for Cowan a historical reminder of the wars, events before his own birth, Wahanui was the great figure of his own time, whom he could recall from memory rather than imagination.

During the 1880 s the aukati was dismantled by attrition through incremental negotiations between John Bryce and Kingtanga leaders such as Wahanui. By 1883, when Cowan was 13 years old, Bryce had largely opened the way for the Rohe Pōtae to be surveyed, for a railway to be built and even for the introduction of the Native Land Court. The government's general pardon, which most notably protected Te Kooti, had finally given credence to John Bryce's assertions that Tāwhiao never had an authority independent of the Crown. ${ }^{30}$ Until the pardon, the Rohe Pōtae was a place of sanctuary, beyond the grasp of the colonial police and the colonial courts.

So quickly did the aukati dissolve that an observer such as Mary Rolleston who rode with John Bryce from Kāwhia to Alexandra in 1883, could look back on the Māori world of 1878 when Grey and Tāwhiao had met at Hikurangi with many thousands present, as a time already passed into distant memory. Looking at the ruins of Hikurangi she reflected that in 1878 Tāwhiao's house had been "surrounded by an armed guard of several hundred menand no one was allowed to approach his sacred person without the utmost ceremony \& formality." Less than five years on, everything had changed. "Now-King Tāwhiao is aimlessly wandering about the country_provoking Europeans \& Maori alike to exclaim'Can this poor drunkard be a King'? - and our little party is riding through his Majesty's dominions in defiance of the "Aukati." 31 Tāwhiao's ability only a year later to remake himself as the hit of the London season, a top-hat-wearing frequenter of the Royal boxes in the city's theatres-drinking only ginger ale-should have undermined Rolleston's harsh assessment, but only accentuated the impression of changing times. ${ }^{32}$ In the days of Cowan's youth, travel through time was a physical act of crossing the aukati. After the 1880s this was no longer possible, or at least was a much rarer event.

Reaching into this lost past became a literary or an artistic task. Cowan was far from alone in fostering a culture of nostalgia. He saw himself with Charles Goldie and Gottfried Lindauer as retrieving the past and admired salvage ethnologists such as Elson Best and Edward Tregear. Tregear the surveyor had been billeted by a neighbour while Cowan was a child; and as Roger Blackley's article in this issue shows, Cowan wrote commentaries for a volume of Lindauer's paintings. ${ }^{33}$ Cowan's use of time to define cultural difference was not unique or even unusual. The prevailing European perception of ethnic difference for most of the 19th century and even beyond was not one of race and biology, or even of colour, but one of history. ${ }^{34}$ According to this view, Māori communities lived in the European past. Amalgamation and assimilation were about bringing Māori from that past into the present world of protestant Christianity and progress. ${ }^{35}$ The contrasts in landscapes imprinted on European visitors' memories the idea of time travel. Those Europeans who came to the big hui of $1878-85$, some of them lasting for 10 days to a fortnight and with 5000 to 7000 participants assembled, saw themselves walking back into the past in seeing a world that no longer existed elsewhere in the colony. In 1878 Grey was welcomed with a 1500-strong haka, after riding up the Waipa on a fleet of waka taua racing alongside each other. ${ }^{36}$ Grey and his 
party had progressively discarded modernity along the journey from Auckland, going from train, to steamer, to waka, to horse, to walking track.

Being keepers of the past, using memory to recreate lost times, made such visitors witnesses to change and more importantly to its speed. John Gorst - a magistrate in the Waikato before the war, until Rewi expelled him-and who became one of Cowan's informants, was one of these. Cowan accompanied him on his return to New Zealand in 1906. Gorst described the changes at Taupiri:

From the high peak of Taupiri on the right bank, the once sacred mountain of the Maories, most of the timber seemed to have been cut away, and the base so sacred in former days that no traveller could proceed up the river on that shore, but must needs cross in a canoe to the left bank, was now desecrated by a railway station and cutting, and the screams and smoke of locomotive engines. ${ }^{37}$

Cowan used a similar contrast to evoke stories of the war itself, stories he saw so quickly being forgotten:

Many a white veteran and many a Maori can still tell of battle adventures, of stormings and defences, of daring scouts and man-huntings, in country that is now disturbed by nothing more alarming than the railway engine's whistle or the motor horn of the well-off dairy farmer. ${ }^{38}$

The past was so quickly being displaced in the landscape that it weakened the natural association of place with memory. In 1937, Cowan returned to Tauranga, "luxuriating in the easy swiftness" of a friend's car, in contrast to the days of travel by horse or in trap or coach. Tauranga had been so transformed that he could no longer make out the battle site of Gate Pā, making it difficult to "reconstruct" the battle site in imagination from what remained. In the late 1890s, the trenches were still there covered in a wilderness of gorse, reminders of the "ground where the Ngaiterangi warriors, in spite of the terrific battering their parapets and shallow burrows had received from the British artillery at close range, yet repulsed more than 100 casualties of the navel and military storming party." 39

There was nothing new in the ideas Cowan repeated so often in his writing: they were engrained in European imagination. But they were also shared by many Māori, including Āpirana Ngata and Te Rangi Hīroa, who described the world of the old time Māori as long passed. ${ }^{40}$ Even different Māori memories, memories that departed from a common consensus, had their place. Cowan celebrated the story of a group of Māori schoolgirls idealising the memory of Te Kooti. When asked by a teacher about Te Kooti "their eyes lit up... They all admired Te Kooti, he was the greatest Maori warrior, he was a great general, and a very good man indeed." When asked by the teacher if he was a cruel man, "Maori eyes blazed with indignation," as they explained how badly treated he had been by the government. Cowan quoted his source with approval when she affirmed that "There is hope for the race.... The young generation holds so tenaciously to their national hero worship."41

Cowan believed that the combatants of the 1860s had learnt to treat each other with respect during the 1880s and 1890s. Gilbert Mair outlined to Cowan a meeting with his old adversary Te Kooti on 12 January 1884. Te Kooti was at Matatā in the Bay of Plenty when he heard that Mair was staying in the nearby Horseshoe Inn. Te Kooti assembled around thirty of his men, and they marched before the hotel, armed with shotguns and borrowed rifles. Mair inspected that guard and was presented with a korowai (cloak) which Te Kooti draped around his shoulders with the words, "Wear the korowai in memory of me, and if it not be large enough to cover you, let me clothe you with my love." 42 After the meeting Mair sent over a bottle of rum, at Te Kooti's request. In having the account of what became a wellknown incident related directly to him by Mair, Cowan himself became a witness to the 
reconstruction of relationships. His reliance on Mair as a source for the campaign against Te Kooti inevitably gave him a more nuanced and benevolent view of the East Coast leader and warrior. After all, following the meeting with Te Kooti at Matatā Mair described his old adversary as "a wonderful man." 43 His brother, William Mair, refused to meet Te Kooti in Rotorua, but still had his own experiences of reconciliation with the defenders of Ōrākau, to whom he had conveyed Cameron's offer of safety in surrender. When a sitting of the Land Court was adjourned in 1886, William was greeted by a "grey-haired deeply tattooed man, approaching him with a tokotoko or walking staff in his hand." Hauraki Tonganui of Ngāti Tūwharetoa and Mair had faced each other over the "parepare" at Örākau, and Tonganui claimed to have been the one to reply on Rewi's behalf. ${ }^{44}$

The negotiations to "open up the King Country" were exercises in peacemaking, attempts by both sides to resolve the tainted legacy of the war. Peace-making involved both high level diplomatic negotiations and personal reconciliations. Soldiers from both sides came together and exchanged war stories. The underlying tensions were still there and the Kingitanga debated how to approach its one-time enemy. At one negotiation, they agreed not to talk about the war, to avoid the questions of who was at fault. ${ }^{45}$ When Hopa te Rangiawini, a figure familiar to Cowan, strayed onto this ground, he was politely told to sit down. At the following hui, things were very different. Te Ngākau of Ngāti Hauā repeatedly asked what he had done wrong, throwing responsibility for the conflict back on Sir George Grey. ${ }^{46}$

Personal histories were easier to reconcile than questions which encroached on sovereignty or the confiscation. Ex-combatants shared memories around camp fires, as much to break the boredom of the long periods of inactivity that were inevitably associated with these meetings. At one, Rewi was approached by an ex-soldier who defended the Number 3 Redoubt from an attack by Ngāti Maniapoto and Raukawa at Hikurangi in Taranaki in 1864. Rewi responded by shaking the man's hand and saying: "You and I have fought, but this is the first time we have talked face to face. Formerly gun powder smoke obscured our eyesight." Rewi asked for the loan of the man's meerschaum pipe, which was handed over. Rewi responded "this is a proof that there is no enmity between us; that you have forgotten old differences." 47 Long before Cowan shaped these borderland events into stories which echoed the American West, both Māori and Pākehā were applying images of burying hatchets and smoking peace pipes to their own exchanges.

These accommodations between old adversaries allowed Cowan to come to his now controversial conclusion that "The wars ended with a strong mutual respect, tinged with a real affection, which would never have existed but for this ordeal by battle." 48 Cowan was also well aware that the fundamental stumbling block of these negotiations, the question of the confiscations, had never been resolved, not in the 1880s, not in the 1920s with the hearings of the Sim Commission into confiscated lands - on which Cowan had considerable influence - and not by the late 1930s, when his attacks on the confiscations became more trenchant.

While personal peacemaking could be heartfelt and largely complete, peacemaking associated with broader political objectives depended on the outcomes politically possible, not on the goodwill of the parties at the time. Personal reconciliation, in Cowan's view, was also about the honour of soldiers, something quite separate from the greed of the politicians who sent them to war. He distinguished between the "chivalrous" troops who became increasingly disillusioned by the injustice of their task and the politicians who planned the "land-grab war." 49 It was the politicians he blamed for the injustice:

So the land on which all these thousands of farm homesteads and all these wealthy towns stand cost nothing but human blood and suffering. Whatever the fault of the Maori, it was forcible robbery on an enormous scale, without any consideration of the men and women who fought for their rights. ${ }^{50}$ 
Elsewhere he described the taking of Māori churches as part of the "vast property looted (the Pakeha mildly called it confiscation)." "It was not just the taking of the land, but the farms, villages, mills and churches, which were described as "stripped" from the Māori.

These depictions of the war reflected a hardened of his views by the late 1930s. Discussing the once Māori, now European, church of St. John's at Rangiaowhia, he wrote "... it is now solely used by the pakehas of the parish. Not a Maori enters it today. Its worshippers were shot down or dispersed when the peaceful gardens of Rangiaowhia became a battlefield in $1864 \ldots . . .52$ His attack on European blindness to what he saw as an old injustice perpetuated reached a crisis when his strongly worded account was censored for his edition of the centenary history series. Cowan recognised that the Māori population was increasing, and that landlessness was not only the historical grief of the confiscation but a growing economic problem for contemporary Māori. He was won over by Te Puea Hērangi's appeals for parliamentarians' support in developing what land Māori retained. In articulating the grievances of confiscation he acknowledged the aspirations of the contemporary Kingitanga. Cowan's rhetoric repeated that of Te Puea, spreading the message with little if any refashioning to his own ideas. ${ }^{53}$ Confiscation was the unfinished business of the negotiations of the 1870s and 1880s.

Cowan's ability to locate himself personally in a historical time, prior to the collapse of his own frontier, also provide some clues to the increasing interest in his life and his work since the beginning of this century. By 1940 he was being superseded as a historian, by a professionally qualified generation who used documentary sources, particularly primary sources, to create a professional distance between the past and the historian. ${ }^{54}$ The highly professionalised approach to New Zealand history, championed by such historians as Keith Sinclair and W. H. Oliver from the 1950s, was concerned with focusing the tools of an international scholarship on New Zealand and its past. Despite the nationalism of this new historiography, Cowan had little time for such an approach, even saw no need for it. In his history, the vitality of storytelling through oral history matched his own nationalist agenda, as he aimed to create a truly popular culture, a past that could be shared widely through the excitement of its shared narratives and the accessibility of its style.

The historians of the 1960s could rely on a new audience not available to Cowan, the academically educated wave of baby-boom graduates emerging from rapidly expanding New Zealand universities. However, in more recent decades, Māori history has been increasingly tied to Māori communities' own understanding of their history and through the Waitangi Tribunal's investigations to their political agendas. Historians can no longer write on the people who inspired Cowan's interest from an impersonal elevation, protected by their professionalism from contact with or accountability to their communities. Notions of professionalism have changed. More recent generations of New Zealand historians, both Māori and non-Māori, have had to work with communities, to take their understandings of the past seriously, as Cowan did a century ago. Cowan never escaped being part of the colonial frontier, nor it should be said from the colonising frontier, but his sensitivity to the people he worked with and their stories provides a model in the present. This is not so much because of his skill as a historian, but because of the positive relationships and friendships he formed with the network of Māori and Pākehā who animated his history. O. N. Gillespie, who knew him well, said of him:

If he could arrange his own Paradise, it would be a "peach orchard in a clearing and sunny always." He would want as well, I think, in this private Valhalla, to have his Maori friends dropping in and the ghosts of Gilbert Mair and Colonel Porter would be welcome. ${ }^{55}$ 
${ }^{1}$ Peter Gibbons, "Non-Fiction," in The Oxford History of New Zealand Literature in English, ed. Terry Sturm (Auckland: Oxford University Press, 1998), 55; Chris Hilliard, "James Cowan and the Frontiers of New Zealand History," NZJH 31, no. 2 (1997): 219-33; Hilliard, "Island Stories: The Writing of New Zealand History, 1920-1940" (MA Thesis, University of Auckland, 1997); Hilliard, The Bookmen's Dominion: Cultural Life in New Zealand 1920-1950, AUP studies in cultural and social history 3 (Auckland: Auckland University Press, 2006). Annabel Cooper takes a similar approach, although more concerned with popular rather than literary culture: Annabel Cooper, "'Our old friends and recent foes' : James Cowan, Rudall Hayward and Memories of Natural Affections in the New Zealand Wars," Journal of New Zealand Studies (online) 14 (2013): 152-70.

2 David Colquhoun, “Cowan, James, 1870-1943," updated 7 July 2005, Dictionary of New Zealand

Biography, http://www.dnzb.govt.nz/, viewed 5 January 2015.

${ }^{3}$ Ibid.

4 "Description of Orakau," New Zealand Herald, 30 June 1875, 1.

${ }^{5}$ Mair to Under Secretary Native Affairs, 31 August 1881, AJHR, 1881, G9.

${ }^{6}$ The Urewera was also an independent Rohe Pōtae, and remained independent for a further decade, but its isolation gave it a lesser significance; see Judith Binney, Encircled Lands : Te Urewera, 18201921 (Wellington, N.Z.: Bridget Williams Books, 2009).

${ }^{7}$ Frederick Jackson Turner, The Frontier in American History (New York: H. Holt, 1920); Richard W. Etulain, Does the Frontier Experience make America Exceptional? Historians at Work (Boston: Bedford/St. Martin's, 1999).

${ }^{8}$ Oriwa Keripi [O. N. Gillespie], “Famous New Zealanders: James Cowan”, no. 37, New Zealand Railways Magazine , 1 April 1936, 25. [Note: it is famous NZers no 37, not volume 37.]

${ }^{9}$ James Cowan, The Old Frontier : Te Awamutu, the Story of the Waipa Valley (Te Awamutu: Waipa Post Printing and Publishing Company, 1922), 84.

${ }^{10}$ Much of this discussion comes from an upcoming book, Dancing with the King: Diplomacy and the Opening of the Rohe Pōtae (forthcoming, Auckland University Press), but see also David McCan, Whatiwhatihoe: the Waikato Raupatu Claim (Wellington: Huia Publishers, 2001) and Cathy Marr, "Te Rohe Potae Political Engagement, 1864 - 1886," (Wellington: Waitangi Tribunal, 2011); Donald Loveridge, "'In accordance with the will of Parliament' The Crown, the Four Tribes and the Aotea block, 1885 - 1899," (Wellington: Crown Law, 2013); Loveridge, "The Crown and the Opening of the King Country, 1882-1885," (Wellington: Crown Law, 2006); Paul Thomas, "The Crown and Maori in Mokau, 1840-1911," (Wellington: Crown Foresty Rentals Trust, 2011); Ann R. Parsonson, "Te Mana o te Kingitanga Maori a Study of Waikato-Ngatimaniapoto Relations During the Struggle for the King Country, 1878-84" (MA, University of Canterbury, 1972).

${ }^{11}$ Sally Maclean. "Searancke, William Nicholas," from the Dictionary of New Zealand Biography. Te Ara - the Encyclopedia of New Zealand, updated 30-Oct-2012, URL:

http://www.TeAra.govt.nz/en/biographies/2s10/searancke-william-nicholas, viewed 22 Janary 2015. ${ }^{12}$ These meetings were widely covered in newspapers and in the Appendices to the Journals of the House of Representatives. See Waikato and Waitara, Native Meetings, Reports of meetings between the Hon. The Premier, The Native Minister, and Natives, AJHR, 1878, G3.

${ }^{13}$ James Cowan, The Maori, Yesterday and To-day (Christchurch: Whitcombe \& Tombs, 1930) 198.

14 "Old Church Demolished," Auckland Star, 20 February 1931,14.

15 James Cowan, The New Zealand Wars: A History of the Maori Campaigns and the Pioneering Period, Vol. I: 1845-64, (rpt. Wellington, P.D. Hasselberg, Government Printer, 1983), Vol. I, 365. 16 "Orakau," Auckland Star, 17 March 1914.

${ }^{17}$ James Cowan, Settlers and Pioneers (Wellington: Department of Internal Affairs, 1940), 79.

${ }^{18}$ This was a point strongly made by Keith Sorrenson in 1963: M. P. K. Sorrenson, "The Maori King Movement, 1858-1885," in Studies of a Small Democracy; Essays in Honour of Willis Airey, ed. Robert Macdonald Chapman and Keith Sinclair (Hamilton: Paul's Book Arcade for the University of Auckland, 1963), 51-52.

19 "The Old Frontier," Auckland Star, 7 May 1930, 6.

${ }^{20}$ Cowan, Settlers and Pioneers, 71-72.

21 "The Old Frontier," Auckland Star, 7 May 1930, 6. 
${ }^{22}$ For Mackay's account see AJHR, 1873 Session I, G-03.

23 "The Old Frontier," Auckland Star, 7 May 1930, 6.

${ }^{24}$ Cowan, Settlers and Pioneers, 51.

25 “Te Kooti’s Story," Auckland Star, 8 June 1912, 12.

26 “"Taua's' Adventures,” ODT, 4 August 1914.

${ }^{27}$ Grant Young and Michael Belgrave, "Raukawa and the Native Land Court, 1865-1910,"

(Auckland: Massey University; Crown Forestry Rental Trust (N.Z.), 2010); Judith Binney,

Redemption Songs. A Life of Te Kooti Arikirangi Te Turuki (Wellington: Auckland University

Press/Bridget Williams Books, 1995), ch. 10-13.

${ }^{28}$ See Cooper, "“Our old friends and recent foes."

29 "Famous New Zealanders: Wahanui, Chief of Ngati-Maniapoto," New Zealand Railways Magazine

23, 1 February 1935, 18.

${ }^{30}$ See Bryce's speech to Tāwhiao, New Zealand Herald, 6 November 1882, 3.

${ }^{31}$ Record of a Journey with her Husband, Daughter and the Hon J Bryce, through the King Country,

Bay of Islands and Rotorua, (typescript) MS-1826, Alexander Turnbull Library, Wellington, 14.

${ }^{32}$ Roger Blackley, "King Tāwhiao's big O. E," Turnbull Library Record, no. 44 (2012), 36-52.

${ }^{33}$ Maori Biographies: Sketches of Old New Zealand Compiled by James Cowan: Descriptive

Catalogue of Maori Portraits Painted by Herr G. Lindauer, Auckland, 1901; see also Roger Blackley,

"The Plutarch of Maoriland: Pictures of Old New Zealand," in this issue.

${ }^{34}$ Pat Moloney, "Savagery and civilisation: Early Victorian notions," New Zealand Journal of History 45, no. 2, (2001): 153-76.

${ }^{35}$ Alan Ward, A Show of Justice. Racial "Amalgamation" in Nineteenth Century New Zealand

(Canberra: ANU Press, 1974); M. P. K. Sorrenson, "How to Civilize Savages: Some 'Answers' from

Nineteenth-Century New Zealand," New Zealand Journal of History 10, no. 2 (1975): 97-111.

${ }^{36}$ Auckland Weekly News, 9 January 1878, 1; Waikato and Waitara, Native Meetings, Reports of meetings between the Hon. The Premier, The Native Minister, and Natives, AJHR, 1878, G3, 1-71.

${ }^{37}$ John Eldon Gorst, New Zealand Revisited. Recollections of the Days of my Youth by the Rt. Hon. Sir John Eldon Gorst, Once Commissioner of the Waikato District, New Zealand (London: Sir Isaac Pitman and Sons, 1908), 300.

${ }^{38}$ Chris Hilliard, "Island Stories," 38; James Cowan, "Chapter I: The Old Race and the New," n.d., Cowan Papers, 39/42C, Alexander Turnbull Library.

39 "Sanctuaries of History: New Zealand's Storied Churches," Auckland Star, 29 May 1937, 10.

${ }^{40}$ Ngata and Te Rangi Hiroa's views are best seen in their willingness to promote the Tohunga

Suppression Act 1907, in the belief that "genuine" tohunga no longer existed; Raeburn T. Lange, May

the People Live: A History of Maori Health Development 1900-1920 (Auckland: Auckland

University Press, 1999).

41 "Te Kooti: The Patriotic Schoolgirls," Auckland Star, 29 June 1935, 1.

42 "The Robe of Love," Auckland Star, 29 June 1935, 1. See Judith Binney's account of the incident in

Redemption Songs, 329-330.

${ }^{43}$ Binney, Redemption Songs, 330.

44 "Orakau," Auckland Star, 17 March 1914.

${ }^{45}$ Waikato and Waitara, Native Meetings, Reports of meetings between the Hon. The Premier, The

Native Minister, and Natives, AJHR, 1878, G3,19.

${ }^{46}$ New Zealand Herald, 12 May, AJHR, 1879, G2, 8-9.

${ }^{47}$ Waikato and Waitara, Native Meetings, Reports of meetings between the Hon. The Premier, The

Native Minister, and Natives, AJHR, 1878, G3, p.11.

${ }^{48}$ James Cowan, The New Zealand Wars: A History of the Maori Campaigns and the Pioneering

Period (Wellington: Govt. Print, 1922), Vol. I, 3.

${ }^{49}$ The Settlement of the Waikato, Miscellaneous Manuscripts, MS-Papers 39-54D, Aexander Turnbull

Library, Wellington.

${ }^{50}$ The Settlement of the Waikato.

51 "Sanctuaries of History," Auckland Star, 29 May 1937.

52 "Sanctuaries of History," Auckland Star, 29 May 1937.

Journal of New Zealand Studies NS19 (2015), 50-62 
${ }^{53}$ Te Puea, the manuscript has an alternate title crossed out, "The Problem of Landless Maoris", MSPapers-11310-80, Alexander Turnbull Library, Wellington; "Famous New Zealanders," New Zealand Railways Magazine 42, 1 September 1936: 17-22. Te Puea, Drafts and Research Papers - Cowan, James, 1870-1943: Papers, MS-Papers-11310-80, Alexander Turnbull Library, Wellington. The manuscript has an alternate title crossed out: "The Problem of Landless Maoris." See also "Famous New Zealanders," New Zealand Railways Magazine 42, 1 September 1936: 17-22.

${ }^{54}$ Chris Hilliard, The Bookmen's Dominion: Cultural Life in New Zealand 1920-1950, AUP studies in cultural and social history 3 (Auckland: Auckland University Press, 2006), 93-96.

${ }^{55}$ Oriwa Keripi [O. N. Gillespie], "Famous New Zealanders: James Cowan," New Zealand Railways Magazine 37, 1 April 1936: 29. 